Gaber EL-Saady et al., Design and simulation of shunt active power filter for Assiut cement company DC motor drive, pp. 2244 - 2259

\title{
DESIGN AND SIMULATION OF SHUNT ACTIVE POWER FILTER FOR ASSIUT CEMENT COMPANY DC MOTOR DRIVE
}

\author{
Gaber EL-Saady ", EL-Noby A. Ibrahim and Mohamed Amin \\ Staff in Electrical Eng., Faculty of Engineering, Assiut University, Assiut 71516, Egypt.
}

Received 26 September 2013; accepted 30 October 2013

\begin{abstract}
This paper introduces a design and simulation of an adaptive shunt active power filter (APF) for harmonic mitigation and power factor (PF) correction of $630 \mathrm{~kW} \mathrm{DC}$ motor (DCM) drive (called By Pass Motor Fan in production line \# 2 in Assiut cement company). Due to the presence of power thyristor converters, a very bad PF and different harmonic components exist in the system, especially in the input current to the DCM drive. All measurements needed for complete analysis at the Medium Voltage (MV) supply source side and at Low Voltage (LV) motor drive side are performed using professional power quality (PQ) analysers and their associated software programs. The studied system is modelled and simulated using MATLAB Simulink software. The instantaneous active and reactive current components $i_{d}$ and $i_{q}$ control method is used in this study to drive the shunt active filter. Therefore the harmonic contents at MV supply source and at point of common coupling (PCC) with the DCM drive are reduced to the standard values. Both digital simulation and practical measurements are presented and consistent. The results show that a good dynamic and steady-state performance of the system is achieved.
\end{abstract}

Keywords: Active power filter, DC motor, harmonics mitigation, power factor correction and power quality.

\section{Introduction}

Connection of the electrical network to nonlinear loads such as rectifiers, inverters, AC regulators, arc furnaces, welding machines, fluorescent lighting, uninterruptable power supplies UPSs, elevators, battery chargers, cranes, steel mills, adjustable speed drives ASDs, etc... cause the appearance of current and voltage harmonics and lower PF [1].Also these nonlinear loads may bring detrimental effects to electric PQ and finally increase the power losses. Moreover, from economical viewpoints, a utility's revenue may get affected at a higher cost. Therefore, efficient solutions for solving these pollution problems have become highly critical for both utilities and customers. Active and passive filters are used for mitigation, elimination or reduction of these effects. Passive power filters (PPFs) have many disadvantages [2], such as their inability to compensate random harmonic current variation. They are designed only for a specific frequency and the possibility of resonance at PCC, tuning problems and filter overloading are all disadvantages of such filters. The other drawback of PPFs is that the sizes of required elements are bulky. The application of APFs for mitigating harmonic currents and compensating for reactive power of the nonlinear load was proposed [3]. The theory and development of APFs have become very popular.

\footnotetext{
* Corresponding author

Email Address: gaber1@yahoo.com
} 
Gaber EL-Saady et al., Design and simulation of shunt active power filter for Assiut cement company DC motor drive, pp. 2244 - 2259

They are the most effective solution used to eliminate harmonic pollution in power systems and have attracted much attention because of their following advantages:

- The capability to compensate random varying currents.

- Good controllability and fast response to system variations.

- High control accuracy.

The APFs appear to be a viable solution for controlling harmonics-associated problems. In operation, the APF injects compensation currents at PCC into the AC lines equal but in opposite direction to distortion, as well as absorbing or generating reactive power, thereby eliminating the unwanted harmonics and compensate for reactive power of the connected load [4]. In this way, the APF cancels out the harmonic currents and leaves the fundamental current component to be provided by the power system and improve the poor system PF [5]. Furthermore shunt APF can keep the power system balanced under the condition of the unbalanced and the nonlinear loads.

\section{Nonlinear Loads Distortion and Harmonic Standards}

Nonlinear loads draw non-sinusoidal current, even when connected to a sinusoidal voltage. Also, the voltage and current waveforms are not of the same shape as shown in Fig.1 and contain fundamental frequency as well as non-fundamental frequencies [6].
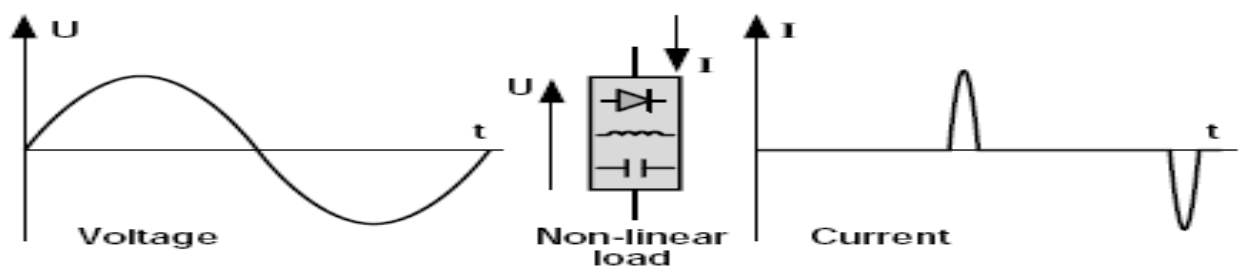

Fig.1. A load is termed non-linear when the current wave-form no longer corresponds to voltage waveform.

The amount of distortion in the voltage or current waveform is quantified by means of an index called the total harmonic distortion (THD). The THD in current is defined as [6]:

$\% T H D=100 \times \frac{\sqrt{\sum_{n=2}^{\infty}\left(I_{n}\right)^{2}}}{I_{1}}$

Where $n$ is the number of the harmonic, THD in the voltage can be calculated in a manner similar to eqn.(1). The significant harmonic frequency currents generated in power conversion equipment can be stated as [7]:

$n=k q \pm 1$

Where $n$ is the significant harmonic frequency, $k$ is any positive integer $(1,2,3$, etc.), and $q$ is the number of power pulses that are in one complete sequence of power conversion.

Journal of Engineering Sciences, Assiut University, Faculty of Engineering, Vol. 41, No. 6, November, 2013,E-mail address: jes@aun.edu.eg 
Gaber EL-Saady et al., Design and simulation of shunt active power filter for Assiut cement company DC motor drive, pp. 2244 - 2259

In the case study of a three-phase full wave bridge rectifier as shown in Fig.2, the number of power pulses is six ( i.e. $q=6$ ) and the following significant harmonics may be generated:

For $k=1, n=(1 * 6) \pm 1=5^{\text {th }}$ and $7^{\text {th }}$ harmonics.

For $k=2, n=(2 * 6) \pm 1=11^{\text {th }}$ and $13^{\text {th }}$ harmonics.

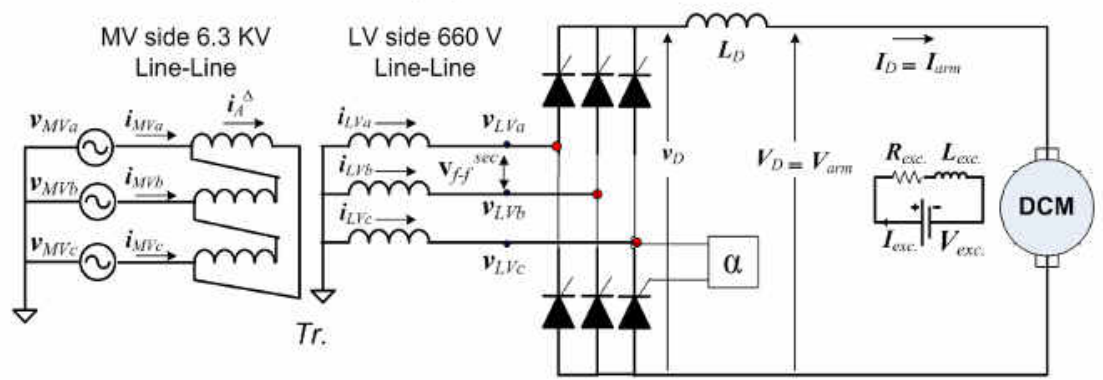

Fig.2. The system under study

With converter circuit shown in Fig.2, harmonics below the $5^{\text {th }}$ harmonic are insignificant. Also, as the harmonic number increases, the individual harmonic distortions become lower due to increasing impedance presented at higher frequency components by the power system inductive reactance. So, typically, the $5^{\text {th }}$ harmonic current would be the highest, the $7^{\text {th }}$ would be lower than the $5^{\text {th }}$, the $11^{\text {th }}$ would be lower than the $7^{\text {th }}$, and so on, as shown below:

$$
\text { I19 }<I 17<I 13<I 11<I 7<I 5
$$

PQ standards (IEEE-519/1992) have specified the limits on the THD of currents and voltages that a user of power electronics equipment and other nonlinear loads is allowed to inject into the utility system.

The harmful effects of harmonic distortion [6] are not known until failure occurs because these harmonic currents circulate in the electrical network (increasing total current's RMS value), disturb the correct operation of the components and even it may damage them, these effects can be divided into 2 groups :

1) Instantaneous effect which may cause interfering with electronics communication and power system protection, such as circuit breaker tripping or blown fuses, malfunction or performance degradation of equipment's and devices, distorted measurements (current, voltage, power, etc...).

2) Long-term effect which may cause reduction the lifetime of the electrical device or equipment, insulation failure, capacitors failures, overheating of the transformers and rotating machines, increased heating in the conductors.

Because of the reasons mentioned above, therefore, a shunt APF is used to eliminate the harmonic components from the power distribution systems.

Journal of Engineering Sciences, Assiut University, Faculty of Engineering, Vol. 41, No. 6, November, 2013,E-mail address: jes@aun.edu.eg 
Gaber EL-Saady et al., Design and simulation of shunt active power filter for Assiut cement company DC motor drive, pp. 2244 - 2259

\section{Description of the System under Study}

Figs. (2 and 3) illustrate the description of the studied system .The studied system consists of a separate excitation DCM, whose field circuit $\left(\mathrm{R}_{\mathrm{exc}}, \mathrm{L}_{\mathrm{exc}}\right)$ is connected directly to a fixed DC supply $\left(\mathrm{V}_{\mathrm{exc}}=113 \mathrm{~V}\right)$. The armature circuit of DCM is connected to three phase power supply $\left(\mathrm{v}_{\mathrm{MVa}}, \mathrm{V}_{\mathrm{MVb}}, \mathrm{V}_{\mathrm{MVc}}\right)$ through a delta star power transformer (Tr.), a six-pulse controlled rectifier thyristor converter called Graetz Bridge and filtering drive inductance $\left(L_{D}\right)$ as shown in Fig.2. All the parameters of study case are listed in Appendix I.

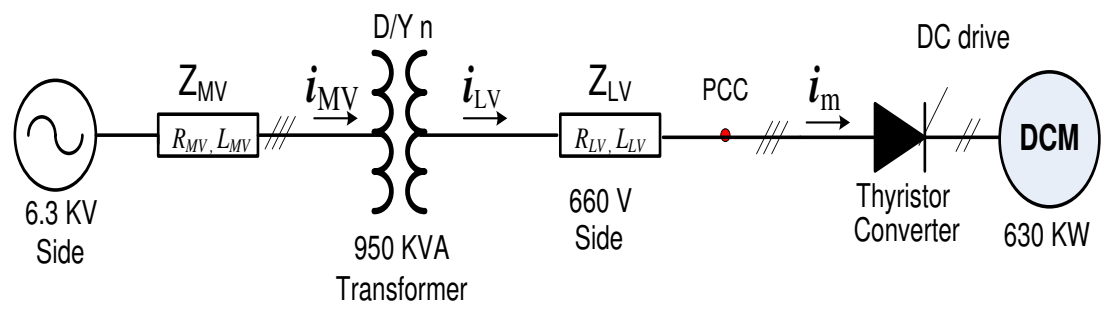

Fig.3. Single line diagram of the studied system

The Torque and speed of DCM are controlled through the drive armature current $\left(I_{D}=I_{a r m}\right)$. The current $I_{a r m}$ is adjusted with $V_{\text {arm }}$, which is controlled by the firing angle $\alpha$ through the following equation [7]:

$V_{\text {arm }}=\frac{3 \cdot \sqrt{2} \cdot V_{f-f}^{\text {sec }}}{\pi} \cos \propto \approx 1.35 \cdot V_{f-f}^{\text {sec }} \cdot \operatorname{Cos} \propto$

Where $V_{f-f}^{s e c}$ is the secondary RMS line voltage, at the thyristor terminals of the converter. The currents generated from rectifier shown in Fig. 2 are far from being sinusoidal. They have the following Fourier series harmonic content for the phase "a" current on the LV side of the Transformer [7]:

$$
i_{L V a}=\frac{2 \sqrt{3}}{\pi} I_{\text {arm }}\left(\cos \omega t-\frac{1}{5} \cos 5 \omega t+\frac{1}{7} \cos 7 \omega t-\frac{1}{11} \cos 11 \omega t+\cdots\right)
$$

The current characteristics obtained from eqn. (5) are:

- The absence of triple harmonics.

- The presence of $6 \mathrm{k} \pm 1$ harmonics for $(\mathrm{k}=1,2,3$, etc).

Due to the power electronics circuitry of ASD, the input supply current to the DCM drive contains various harmonics components.

According to the system configuration shown in Figs.(2 and 3) practical measurements using professional power quality analyzers (see Appendix II) for phase voltages, phase currents and their associated harmonics spectrum of the DCM drive are plotted with FFT analysis for MV side and LV side as shown in Figs.(4 and 5).

Journal of Engineering Sciences, Assiut University, Faculty of Engineering, Vol. 41, No. 6, November, 2013,E-mail address: jes@aun.edu.eg 
Gaber EL-Saady et al., Design and simulation of shunt active power filter for Assiut cement company DC motor drive, pp. 2244 - 2259

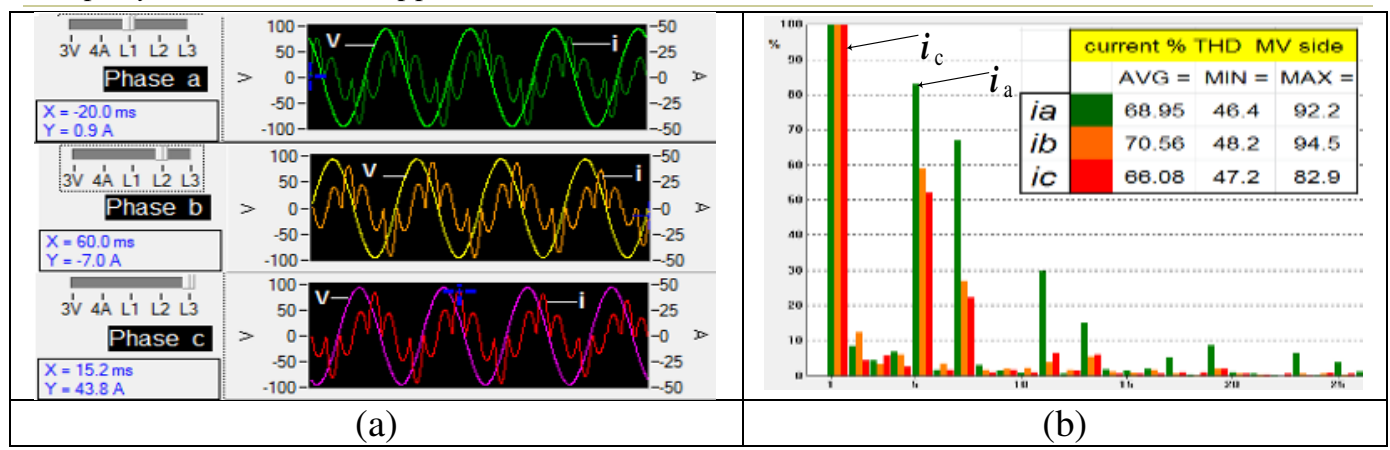

Fig.4. (a) Practical measurements of MV current and voltage waveforms for phase $\mathrm{a}, \mathrm{b}$ and $\mathrm{c}$ before using the APF (for a period $=4$ cycles $=80 \mathrm{~ms}$ ).

The voltage values are scaled by turns ratio of 6300/100.

(b) FFT analysis of the MV current waveforms

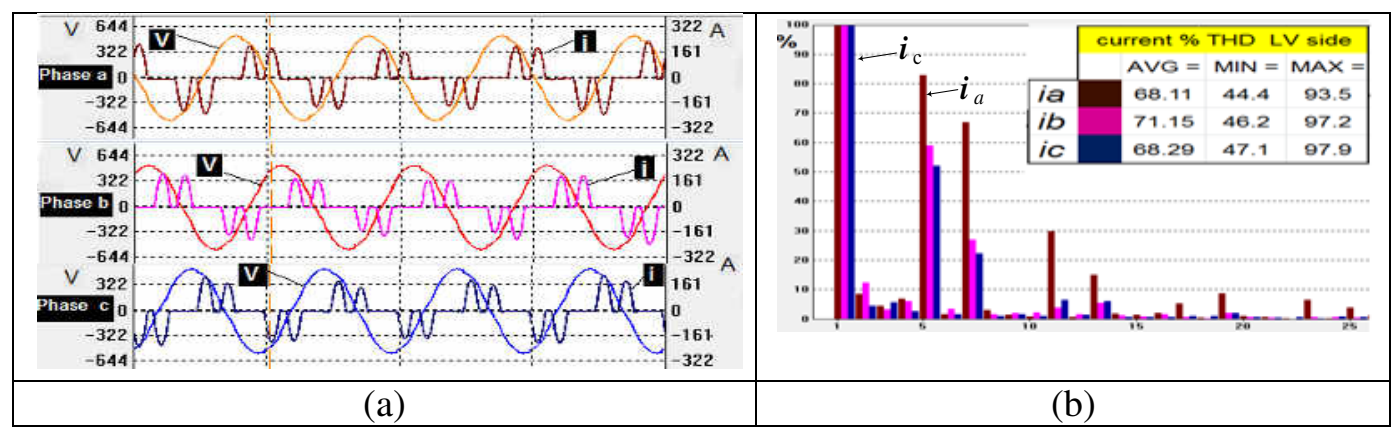

Fig.5. (a) Practical measurements of LV current and voltage waveforms for phase $\mathrm{a}, \mathrm{b}$ and $\mathrm{c}$ before using the APF (for a period $=4$ cycles $=80 \mathrm{~ms}$ ).

(b) FFT analysis of LV current waveform

These practical results show that, the presence of $5^{t h}, 7^{t h}, 11^{\text {th }}$ and $13^{\text {th }}$ harmonic currents and the \% THD of MV and LV currents exceeds the standard values (IEEE519/1992). However the voltage waveforms of MV and LV sides are approximately sinusoidal with acceptable values of THD as listed below in Table 1, and the system PF varies from 0.29 to .32 .

\section{Table 1}

$\%$ THD of phase voltages for phase $\mathrm{a}, \mathrm{b}$ and $\mathrm{c}$ (for a period $=24 \mathrm{~h}$ ).

\begin{tabular}{|c|c|c|c|c|c|c|c|}
\hline \multirow[b]{3}{*}{$v_{M V a}$} & \multicolumn{3}{|c|}{ Voltage $\%$ THD MV side } & & \multicolumn{3}{|c|}{ Voltage $\%$ THD LV side } \\
\hline & Avg. $=$ & Min. $=$ & Max.= & & Avg. $=$ & Min. = & Max. $=$ \\
\hline & 1.02 & 0.90 & 1.20 & $v_{L V a}$ & 4.72 & 3.60 & 6.50 \\
\hline$v_{M V b}$ & 0.97 & 0.80 & 1.20 & $v_{L V b}$ & 4.43 & 3.30 & 6.00 \\
\hline$v_{M V C}$ & 0.90 & 0.70 & 1.10 & $v_{L V C}$ & 4.69 & 3.40 & 6.30 \\
\hline
\end{tabular}

Journal of Engineering Sciences, Assiut University, Faculty of Engineering, Vol. 41, No. 6, November, 2013,E-mail address: jes@aun.edu.eg 
Gaber EL-Saady et al., Design and simulation of shunt active power filter for Assiut cement company DC motor drive, pp. 2244 - 2259

\section{Proposed System with Shunt APF}

The basic compensation principle of APF is to detect the unwanted harmonic components of the line currents $\left(i_{\mathrm{LV}}\right)$, and then to generate and inject a signal into the line in such a way to produce partial or total cancellation of the unwanted components. The APF is controlled using instantaneous active and reactive current component $\mathrm{i}_{\mathrm{d}}-\mathrm{i}_{\mathrm{q}}$ method [8] which provides efficient way to get rid of the harmonics resulted from the system. Such control of the APF is applied through the DCM drive load current $\left(i_{\mathrm{m}}\right)$, filter current $\left(i_{\mathrm{f}}\right)$ and the APF DC voltage $\left(\mathrm{V}_{\mathrm{dc}}\right)$ as shown in Fig. 6. Each component of the proposed control system will be explained in the following subsections.

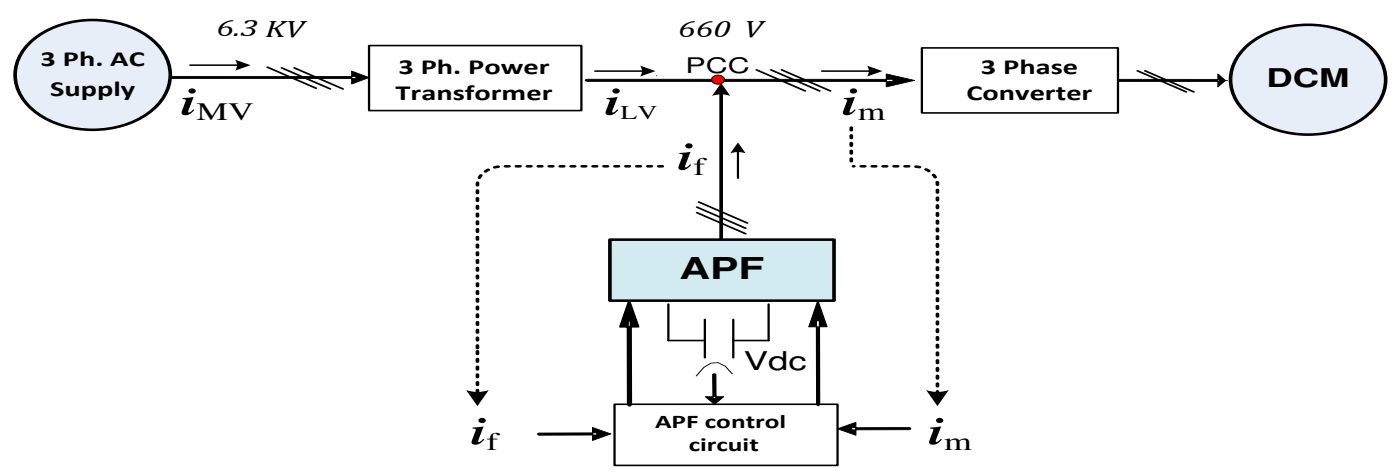

Fig.6. Proposed system with APF schematic diagram.

\subsection{Design of shunt APF system}

The APF with parameters listed in Appendix III is connected in shunt at PCC, which is considered LV load terminals, to reduce harmonics and improve PF with consequential improvement at MV source side. The APF Design criteria shown in Fig.7compose:

- A power inverter circuit (VSI).

- Smoothing inductor $\left(\mathrm{L}_{\mathrm{f}}\right)$.

- Smoothing high frequency filter capacitors $\left(\mathrm{C}_{\mathrm{f}}\right)$.

- DC Capacitor $\left(\mathrm{C}_{\mathrm{dc}}\right)$.

- Control circuit to obtain the reference currents.

The VSI contains three phase isolated gate bipolar transistor (IGBT) with antiparalleling diodes connected to the DC capacitor located at the DC bus of the IGBTs. The DC capacitor serves as an energy storage element for providing a constant DC voltage for real power necessary to cover the APF losses at steady state. The filter capacitance $\mathrm{C}_{\mathrm{f}}$ is used to mitigate the high-frequency ripple components and thus reducing the switching stress on the APF switches [9].

Journal of Engineering Sciences, Assiut University, Faculty of Engineering, Vol. 41, No. 6, November, 2013,E-mail address: jes@aun.edu.eg 
Gaber EL-Saady et al., Design and simulation of shunt active power filter for Assiut cement company DC motor drive, pp. 2244 - 2259

\subsection{Current supplied by the shunt APF}

From Fig.7 it is seen that; APF is controlled to draw/supply a filter compensating current $\left(i_{f}\right)$ from/to the system, so that it cancels current harmonics on the AC side, and makes source current $\left(i_{L V}\right)$ in phase with source voltage $\left(v_{L V}\right)$. In this figure curve $\mathrm{A}$ is the non-linear DCM drive load current $\left(i_{m}\right)$ waveform, curve B is the desired mains current $\left(i_{L V}\right)$ and curve $\mathrm{C}$ shows the filter compensating current $\left(i_{\mathrm{f}}\right)$ injected by APF containing all harmonics, to make mains current sinusoidal as indicated from the following equations [10]:

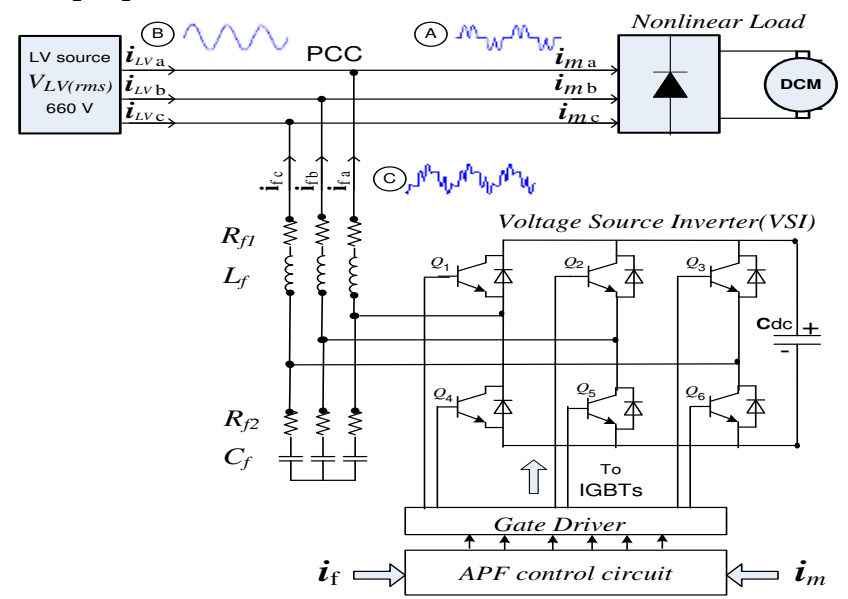

Fig. 7. APF system configuration and current waveforms

Let, the source voltage at LV side is given by

$v_{L V}(\mathrm{t})=\mathrm{V}_{L V} \sin (\omega \mathrm{t})$

The source current at $\mathrm{LV}$ side can be written as

$i_{L V}(\mathrm{t})=i_{m}(\mathrm{t})-i_{f}(\mathrm{t})$.

Where $i_{m}(\mathrm{t}), i_{f}(\mathrm{t})$ are load and filter currents, respectively. The DCM drive load current will contain a fundamental and harmonics components, which can be written as $i_{m}(\mathrm{t})=\sum_{\mathrm{n}=1}^{\infty} i_{n} \sin \left(\mathrm{n} \omega \mathrm{t}+\emptyset_{n}\right)$,

$=\mathrm{I}_{1} \sin \left(\omega \mathrm{t}+\emptyset_{1}\right)+\sum_{\mathrm{n}=2}^{\infty} i_{n} \sin \left(\mathrm{n} \omega \mathrm{t}+\emptyset_{n}\right)$

In (8), there are three terms

$$
i_{m}(t)=\underbrace{I_{1 a} \sin (\omega t)}_{\text {Active }}+\underbrace{I_{1 r} \cos (\omega t)}_{\text {Reactive }}+\underbrace{\sum_{n=2}^{\infty} i_{n} \sin \left(n \omega t+\emptyset_{n}\right)}_{\text {Harmonics }}
$$

Where $\mathrm{I}_{1 \mathrm{a}}=\mathrm{I}_{1} \cos \emptyset_{1}$ and $\mathrm{I}_{1 \mathrm{r}}=\mathrm{I}_{1} \sin \emptyset_{1}$

The instantaneous load power can be given as

$$
\begin{aligned}
p_{m}(\mathrm{t}) & =v_{L V}(\mathrm{t}) * i_{m}(\mathrm{t}) \\
& =\mathrm{V}_{L V} \mathrm{I}_{1 \mathrm{a}} \sin ^{2}(\omega \mathrm{t})+\mathrm{V}_{L V} \mathrm{I}_{1 \mathrm{r}} \sin (\omega \mathrm{t}) \cos (\omega \mathrm{t}) \\
+\mathrm{V}_{L V} \sin (\omega \mathrm{t}) \sum_{\mathrm{n}=2}^{\infty} i_{n} \sin \left(n \omega \mathrm{t}+\emptyset_{n}\right) . & =p_{a}(t)+p_{r}(t)+p_{h}(t) .
\end{aligned}
$$

Journal of Engineering Sciences, Assiut University, Faculty of Engineering, Vol. 41, No. 6, November, 2013,E-mail address: jes@aun.edu.eg 
Gaber EL-Saady et al., Design and simulation of shunt active power filter for Assiut cement company DC motor drive, pp. 2244 - 2259

From (10), the active (fundamental) power drawn by the DCM drive load is

$p_{a}(t)=\mathrm{V}_{L V} \mathrm{I}_{1 \mathrm{a}} \sin ^{2}(\omega \mathrm{t})=v_{L V}(\mathrm{t}) * i_{L V}(\mathrm{t})$

From (12), the source current after compensation is

$i_{L V}(t)=p_{a}(t) / v_{L V}(t)=I_{1 a} \sin (\omega t)$

The APF provides total reactive and harmonic power $\left\{p_{r}(t), p_{h}(t)\right\}$, which the load needs, so $i_{L V}(t)$ will be in phase with utility voltage $v_{L V}(t)$ and will be purely sinusoidal. In this case, APF must provide the following compensation current:

$i_{f}(t)=i_{m}(t)-i_{L V}(t)$.

Hence, for accurate and instantaneous compensation of reactive power and harmonic currents, it is necessary to estimate the fundamental component of the DCM drive load current using instantaneous active and reactive power Theory.

\subsection{Instantaneous power in dqo-Axis}

The instantaneous active and reactive power component theory ( $\mathrm{p}-\mathrm{q}$ theory) is widely used in the APF control circuitry to calculate the desired compensation current [11-16] as shown from the following equations:

The voltage and current in $d q 0$ axis can be obtained from $a b c$ axis by Clark transformation [16]:

$\left[\begin{array}{l}i_{q} \\ i_{d} \\ i_{\circ}\end{array}\right]=\sqrt{\frac{2}{3}} \cdot\left[\begin{array}{ccc}0 & \frac{-1}{2} & \frac{-1}{2} \\ 1 & \frac{-\sqrt{3}}{2} & \frac{\sqrt{3}}{2} \\ \frac{1}{\sqrt{2}} & \frac{1}{\sqrt{2}} & \frac{1}{\sqrt{2}}\end{array}\right] \cdot\left[\begin{array}{c}i_{a} \\ i_{b} \\ i_{c}\end{array}\right]$

Also, the voltage and current in abc axis can be expressed from $d q 0$ axis using Clark transformation inverse [16]:

$\left[\begin{array}{l}i_{a} \\ i_{b} \\ i_{c}\end{array}\right]=\sqrt{\frac{2}{3}} \cdot\left[\begin{array}{ccc}1 & 0 & \frac{1}{\sqrt{2}} \\ \frac{-1}{2} & \frac{-\sqrt{3}}{2} & \frac{1}{\sqrt{2}} \\ \frac{-1}{2} & \frac{\sqrt{3}}{2} & \frac{1}{\sqrt{2}}\end{array}\right] \cdot\left[\begin{array}{c}i_{q} \\ i_{d} \\ i_{\circ}\end{array}\right]$

Phase voltages in $d q 0$ axis can also be obtained by eqn. similar to eqn.(15)

The Instantaneous power is equal to

$$
\begin{array}{ccc}
p=1.5\left(v_{d} i_{d}+v_{q} i_{q}\right) & \text { Active power } \\
q=1.5\left(v_{d} i_{q}-v_{q} i_{q}\right) & \text { Reactive power } \\
p_{\circ}=3 v_{\circ} i_{\circ} & \text { Zero power component }
\end{array}
$$

Eqn. (17) can be rewritten in matrix form as:

$$
\left[\begin{array}{c}
p \\
q \\
p_{\circ}
\end{array}\right]=1.5\left[\begin{array}{ccc}
v_{q} & v_{d} & 0 \\
v_{d} & -v_{q} & 0 \\
0 & 0 & 2 v_{o}
\end{array}\right] \cdot\left[\begin{array}{c}
i_{q} \\
i_{d} \\
i_{\circ}
\end{array}\right]
$$

The instantaneous active and reactive power can be expressed as the sum of AC and DC values as follows:

Journal of Engineering Sciences, Assiut University, Faculty of Engineering, Vol. 41, No. 6, November, 2013,E-mail address: jes@aun.edu.eg 
Gaber EL-Saady et al., Design and simulation of shunt active power filter for Assiut cement company DC motor drive, pp. 2244 - 2259

$$
p=\bar{p}+\tilde{p} \quad \text { and } \quad q=\bar{q}+\tilde{q}
$$

Where $\bar{p}$ and $\bar{q}$ are the DC values of active and reactive components respectively. These components are created from positive sequence component of the load current.

The AC values of $\mathrm{p}$ and $\mathrm{q}(\tilde{\mathrm{p}}, \tilde{\mathrm{q}})$ are produced from harmonic components of the load current .One of the benefits of eqn.(18) is that the $\tilde{p}, q, p_{\circ}$ can be compensated using the following equation

$$
\left[\begin{array}{ll}
i_{f} & q \\
i_{f} & d
\end{array}\right]=\frac{1}{v_{d}^{2}+v_{q}^{2}}\left[\begin{array}{cc}
v_{q} & v_{d} \\
v_{d} & -v_{q}
\end{array}\right] \cdot\left[\begin{array}{c}
-\tilde{p}-p_{\circ} \\
-q
\end{array}\right]
$$

With inverse Clark transformation, reference currents for APF can be found as follows:

$$
\left[\begin{array}{l}
i_{\text {ref }} a \\
i_{\text {ref } b} \\
i_{\text {ref } c}
\end{array}\right]=\sqrt{\frac{2}{3}} \cdot\left[\begin{array}{ccc}
1 & 0 & \frac{1}{\sqrt{2}} \\
\frac{-1}{2} & \frac{-\sqrt{3}}{2} & \frac{1}{\sqrt{2}} \\
\frac{-1}{2} & \frac{\sqrt{3}}{2} & \frac{1}{\sqrt{2}}
\end{array}\right] \cdot\left[\begin{array}{c}
i_{f} q \\
i_{\text {f }} \\
0
\end{array}\right]
$$

\section{APF Control Method}

The quality and performance of the shunt APF is based on control circuit to generate the reference currents, that must be provided by the filter to compensate load reactive power and harmonic currents. This involves a set of currents in the phase domain, which will be tracked generating the switching signals applied to VSI by means of the hysteresis control switching technique, such that the desired current reference is exactly followed.

\subsection{Compensating reference current}

The control strategy for a shunt APF configuration requires the measurement of both the actual load and filter currents. The actual filter currents are compared with reference currents as shown in Fig.8. The comparison result is fed to gate pulse generation system with hysteresis band control. Hysteresis band current regulators have been widely used for APF applications because of their high bandwidth, simple structure and it is the fastest control with minimum hardware and software.

As illustrated in Fig. 8, the distorted measured DCM drive load currents $\left(i_{m a}, i_{m b}, i_{m c}\right)$ are transferred into synchronous rotating reference frame $\left(\mathrm{i}_{\mathrm{md}}, \mathrm{i}_{\mathrm{mq}}\right)$ using abc to dqo transformation block [8] and the phase locked loop (PLL) circuit to maintain the synchronization with supply system. Using a high pass filter (HPF), the harmonic components of total active load current are extracted. Then AC active current harmonic components $\left(\mathrm{i}_{\mathrm{mdh}}=\sum_{\mathrm{n}=2}^{\infty} \mathrm{i}_{\mathrm{mdh}}\right)$ are derived. The reactive power flow is controlled by the fundamental harmonic quadrature current $\mathrm{i}_{\text {mq }}$. However, considering the primary end of the APF is simply to eliminate current harmonics caused by nonlinear loads, the current $\mathrm{i}_{\mathrm{q} 1}$ is set to zero [8] as shown in Fig. 8. The harmonic reference currents $\left(i_{d \text { ref }}, i_{\mathrm{q} \text { ref }}\right)$ are transformed to $\left(\mathrm{i}_{\text {refa }}, \mathrm{i}_{\text {refb }}, \mathrm{i}_{\text {refc }}\right)$ through $d q 0$ to $a b c$ transformation block.

Journal of Engineering Sciences, Assiut University, Faculty of Engineering, Vol. 41, No. 6, November, 2013,E-mail address: jes@aun.edu.eg 
Gaber EL-Saady et al., Design and simulation of shunt active power filter for Assiut cement company DC motor drive, pp. 2244 - 2259

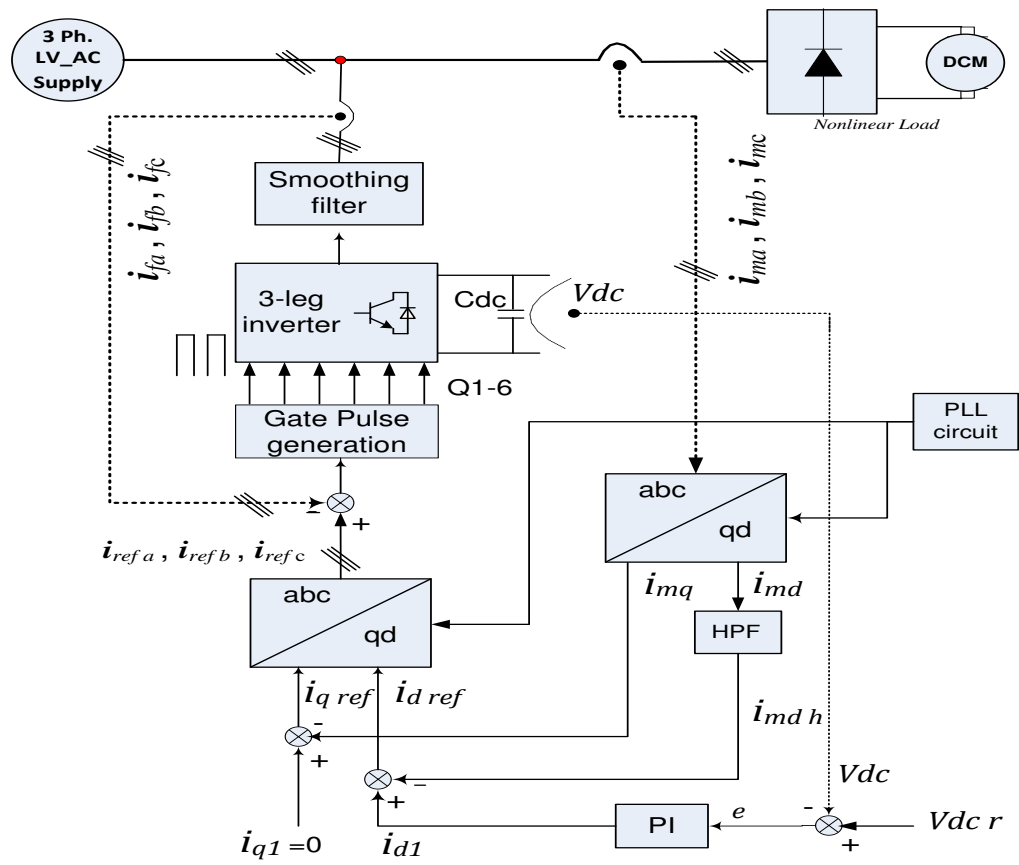

Fig.8. APF control circuit by using the instantaneous active and reactive current component method.

\subsection{DC voltage regulation}

The DC bus proportional integral PI controller shown in Fig. 8, regulates the DC bus voltage $V_{d c}$ to its reference value $V_{d c r}$, and compensates for the inverter losses. The DC capacitor voltage is sensed and then compared with a reference value. The obtained error ( $\mathrm{e}=V_{d c r}-V_{d c}$ ) is used as input for PI controller, the DC bus controller generates a fundamental harmonic direct current $i_{d 1}$ to provide the active power transfer required to regulate DC bus voltage and compensate the inverter losses.

\subsection{The gate pulse generation system}

In this paper, a shunt APF with hysteresis band control is used to compensate the disadvantages appearing due to the use of nonlinear load. As shown in Fig. 9, it consists of the hysteresis current controller with fixed band, which derives the switching signals of the VSI from the current error. The harmonic reference currents $\left(i_{\text {refa }}, i_{\text {refb }}, i_{\text {refc }}\right)$ are compared to the actual filter currents $\left(i_{f a}, i_{f b}, i_{f c}\right)$, and produce the error which is the input to the hysteresis current controller to keep the current within the hysteresis band and to produce gate switch control pulses $\left(\mathrm{Q}_{1}-\mathrm{Q}_{6}\right)$ for the IGBTs bridge of the VSI.

Journal of Engineering Sciences, Assiut University, Faculty of Engineering, Vol. 41, No. 6, November, 2013,E-mail address: jes@aun.edu.eg 
Gaber EL-Saady et al., Design and simulation of shunt active power filter for Assiut cement company DC motor drive, pp. 2244 - 2259

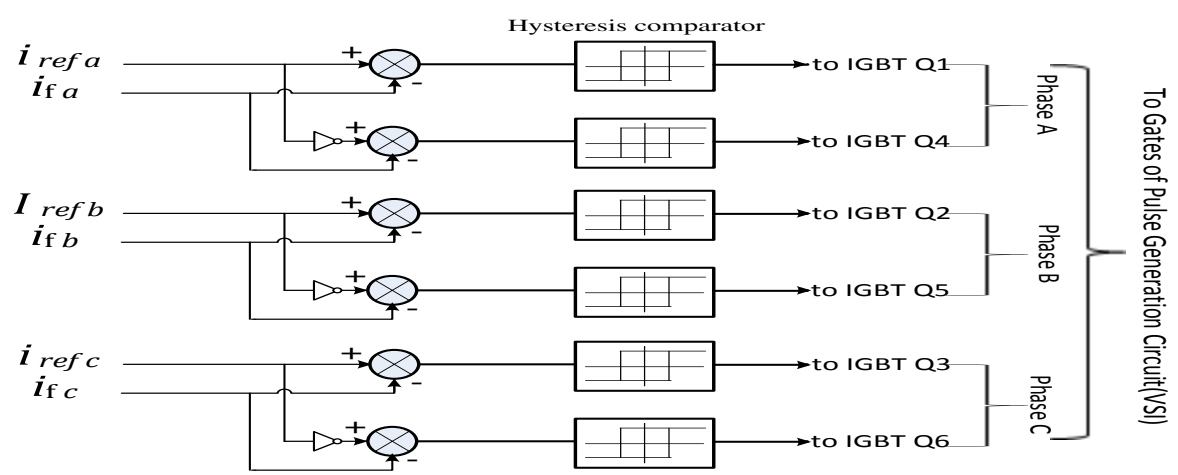

Fig.9. Gate pulse generation system using hysteresis control.

\section{Simulation Results and Discussion}

To evaluate the operating performance of the designed system with and without adaptive shunt APF, a 3-phase system is built using MATLAB Simulink. The system model as illustrated in Figs.(2 and 3) consists of fundamental supply voltage at MV side $\left(v_{M V}\right)$ connected to a power transformer $(\mathrm{Tr}$.) through MV cable with resistance and inductance $\left(R_{M V}, L_{M V}\right)$.The transformer $(T r$. $) \mathrm{LV}$ side is connected to converter thyristor rectifier through LV cable with resistance and inductance $\left(R_{L V}, L_{L V}\right)$ to DCM inserted into the DC side of the converter. The DCM resistance and inductance of armature and field coils $\left(R_{a}, L_{a}, R_{f}, R_{f}\right)$, inserted into the model are measured practically using professional motor parameter analyser (see Appendix II) .In these simulation studies, the supply voltage $\left(v_{M V}\right)$ is assumed to be sinusoidal.

The phase "a" voltage and current waveforms and their associated THD before and after connecting APF to DCM drive system are illustrated in Figs.(10-14) where:

- $\quad\left(i_{\mathrm{MVa}}, v_{\mathrm{MVa}}\right)$ are MV phase current and phase voltage.

- $\quad\left(i_{\mathrm{LVa}}, v_{\mathrm{LVa}}\right)$ are $\mathrm{LV}$ phase current and phase voltage.

- $\left(i_{m a}\right)$ is the DCM drive current.

- $\left(i_{f a}\right)$ is the injected APF current.

The THD of MV current is $1.28 \%$ and $1.92 \%$ for current at DCM drive LV side against $59.31 \%$ and $90.52 \%$ for the THD of current before using the APF.

Therefore, the APF reduced the THD of DCM Drive current at MV side from 59.31\% to $1.28 \%$ and at $\mathrm{LV}$ side from $90.52 \%$ to $1.92 \%$.

Fig.11 shows, MV current waveform ( $\mathrm{i}_{\mathrm{MVa}}$ ) is approximately in phase with MV voltage waveform $\left(\mathrm{v}_{\mathrm{MVa}}\right)$, hence the $\mathrm{PF}$ is approximately near to unity and from Figs.(11a and 13a) Noting that, the values of current THD decreased when the shunt APF is connected in the system compared to the values of THD without the shunt APF. That means the distortions in the waveforms are decreased and the supply current becomes harmonics free.

Journal of Engineering Sciences, Assiut University, Faculty of Engineering, Vol. 41, No. 6, November, 2013,E-mail address: jes@aun.edu.eg 
Gaber EL-Saady et al., Design and simulation of shunt active power filter for Assiut cement company DC motor drive, pp. 2244 - 2259

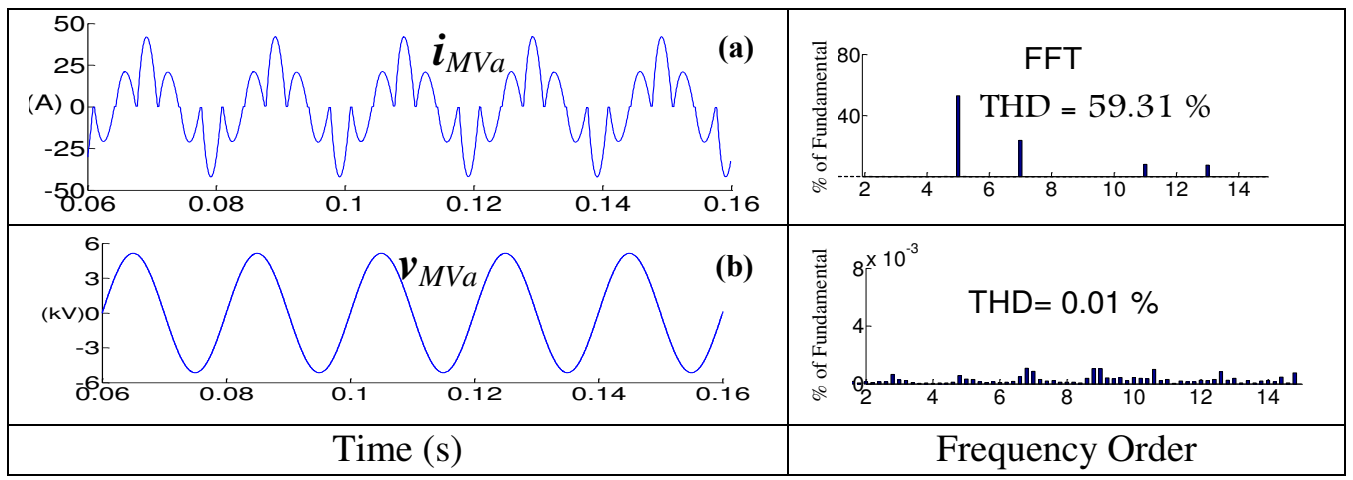

Fig.10. MV side current and voltage waveforms and their FFT spectrum ( from MATLAB Simulink model) for Phase "a" before using the APF

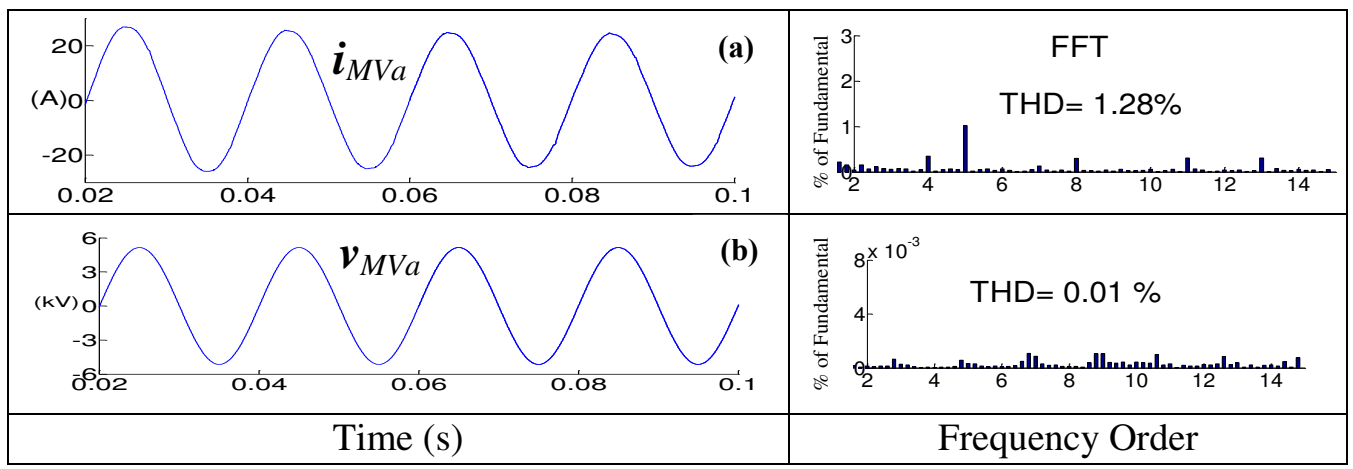

Fig.11. MV side current and voltage waveforms and their FFT spectrum ( from MATLAB Simulink) for Phase "a" after using the APF

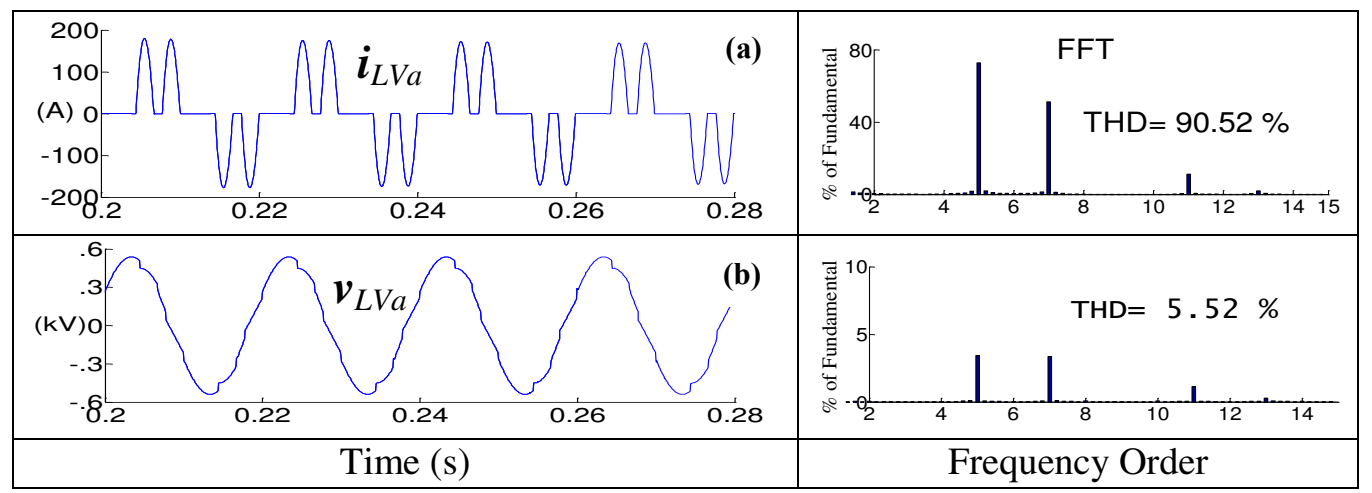

Fig.12. LV side current and voltage waveforms and their FFT spectrum ( from MATLAB Simulink) for Phase "a" before using the APF

Journal of Engineering Sciences, Assiut University, Faculty of Engineering, Vol. 41, No. 6, November, 2013,E-mail address: jes@aun.edu.eg 
Gaber EL-Saady et al., Design and simulation of shunt active power filter for Assiut cement company DC motor drive, pp. 2244 - 2259

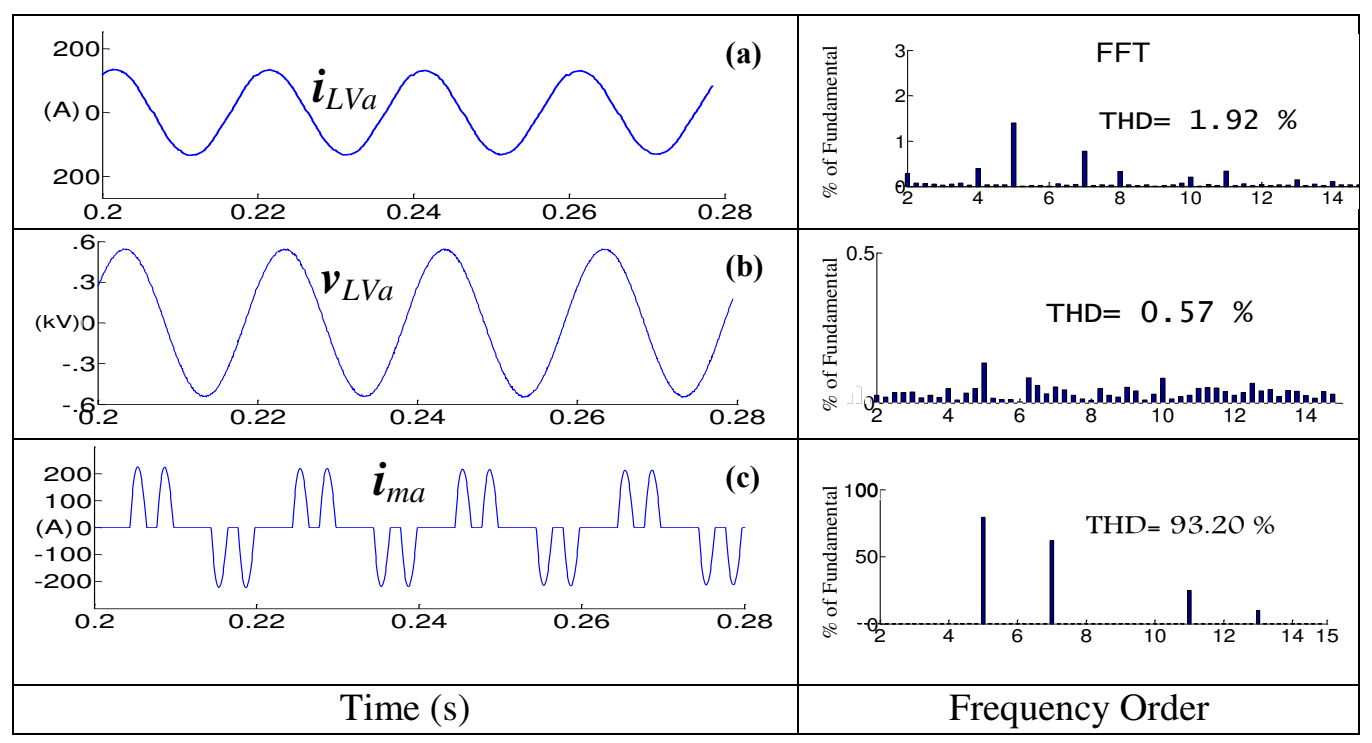

Fig.13. LV side currents and voltage waveforms and their FFT spectrum (from MATLAB Simulink) for Phase "a" after using the APF

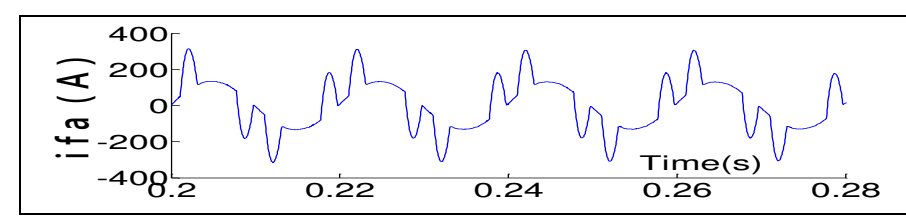

Fig.14. Injected APF current waveform (from MATLAB Simulink) for Phase "a"

\section{Conclusions}

In this paper, the performances of the proposed shunt APF were verified through simulation studies using MATLAB under different operating conditions. The simulation results showed that the shunt APF with adaptive control is able to adapt themselves to the variations in the DCM drive load currents. As for the shunt APF, it can correct the supply power factor to near unity besides compensating the harmonic currents present in the DCM drive load current. The shunt APF allows the harmonics present in the utility system to be compensated, providing a good quality of power supply to customers. Since, the design concepts of the proposed shunt APF are obtained. The current analysis and simulation results serve the practical engineer to design control circuit for hardware implementation of the APF for this DCM drive.

Journal of Engineering Sciences, Assiut University, Faculty of Engineering, Vol. 41, No. 6, November, 2013,E-mail address: jes@aun.edu.eg 
Gaber EL-Saady et al., Design and simulation of shunt active power filter for Assiut cement company DC motor drive, pp. 2244 - 2259

\section{References}

[1] Ping. W. ,Zhixiong. Z., Houquan.C., “A DSP-based active power filter for three phase power distribution systems", International Conference on Computer Engineering and Technology,ICCET'09,Singapore, PP.210-214, Jan 2009.

[2] Hugo. A, Ramos. C.,Aurelio. M., Gary W. C., "Real-Time Shunt Active Power Filter Compensation", IEEE Trans. on Power Delivery, Vol. 23, No. 4, OCT. 2008.

[3] G. A. Ramos, R. Costa, J. Olm, "Digital Repetitive Control under Varying Frequency Conditions" Book ,part.3,Ch.7" Shunt Active Power Filter " PP. 101-137, SpringerVerlag Berlin Heidelberg, 2013.

[4] G.W. Chang and C.M. Yeh, "Optimisation-based strategy for shunt active power filter control under non-ideal supply voltages", IEE Proc.-Electr. Power Appl., vol. 152, no. 2, March 2005.

[5] L.Asiminoaei, F. Blaabjerg, S. Hansen, and P.Thøgersen, "Adaptive compensation of reactive power with shunt active power filters", IEEE Trans. On Industry Applications, vol. 44, no. 3, pp. 867-877, MAY 2008.

[6] Francisco C. De La Rosa, "Harmonics and Power Systems", CRC Press, U.S.A. Book 2006.

[7] M. H. Rashid, "Power electronics Handbook "-chapter 12, "three-phase controlled rectifiers" for Juan W. Dixon ,Santiago, CHILE", Academic press, canda, PP.183-210, 2001.

[8] V. Soares, P. Verdelho and G. D. Marques, "An instantaneous active and reactive current component method for active filters", IEEE Trans. on Power Electronics, vol.15, no.4, PP.660-669, JULY 2000.

[9] A. Eid, M. Abdel-Salam, H. El-Kishky, T. El-Mohandes, "Active power filters for harmonic cancellation in conventional and advanced aircraft electric power systems", "Electric Power Systems Research", Vol. 79,issn.1, PP. 80-88, January 2009.

[10] Chaoui et al, Jean Paul, Fateh Krim, G. Champenois, "PI controlled three phase shunt active filter for power quality improvement ", Taylor \& Francis Group, ISSN. 1532-5008, PP. 1331-1344, 2007.

[11] H. Akagi, Y. Kanazawa, A. Nabae, "Instantaneous reactive power compensators comprising switching devices without energy storage components", IEEE Trans. on Industry Applications, pp. 625-630, IA-20 (May/June (3)) (1984).

[12]F.-Z. Peng, G.W. Ott, D.J. Adams, "Harmonic and reactive power compensation based on the generalized instantaneous reactive power theory for three-phase four-wire systems", IEEE Trans. Power Electron, pp. 1174-1181, 13 (Nov. (6)) (1998).

[13] H. Akagi, S. Ogasawara, H. Kim, "The theory of instantaneous power in three-phase four-wire systems: a comprehensive approach", in: Proc. IEEE IAS Annu. Meeting, pp. 431-439, 1999.

[14] J.Afonso, C. Couto, J.Martins, "Active filters with control based on the $p-q$ theory", IEEE Ind. Electron. Soc. Newslett., pp. 5-11, (September 2000).

[15] M. Aredes, E.H. Watanabe, "New control algorithms for series and shunt three-phase four-wire active power filters ", IEEE Trans. Power Delivery, pp. 1649-1656, 11 (July (3)) (1995).

[16] M. Nayeripour, and T. Niknam., "Design of a Three Phase Active Power filter with sliding mode control and energy feedback", proceedings of world academy of science, engineering and technology, issn 1307-6884, vol. 29, pp. 330-336, may 2008.

Journal of Engineering Sciences, Assiut University, Faculty of Engineering, Vol. 41, No. 6, November, 2013,E-mail address: jes@aun.edu.eg 
Gaber EL-Saady et al., Design and simulation of shunt active power filter for Assiut cement company DC motor drive, pp. 2244 - 2259

\section{APPENDIX I}

The values of DCM drive system parameters that used in simulation are shown in the table below.

\begin{tabular}{lc}
\hline DC Motor Parameters & $630 \mathrm{KW}$, separate excitation \\
Rated \{ voltage, current, speed $\}$ & $750 V_{d c}, 902 A_{d c}, 490 \mathrm{rpm}$ \\
Excitation \{voltage, current & $113 V_{d c}, 34 A_{d c}$, \\
Armature resistance\& inductance, $R_{a}, L_{\mathrm{a}}$ & $32.5 \mathrm{~m} \Omega, 0.56 \mathrm{mH}$ \\
Field resistance\& inductance, $R_{f}, L_{f}$ & $3.045 \Omega, 1.264 \mathrm{H}$ \\
Field-armature mutual inductance $L_{a f}$ & $145.6 \mathrm{mH}$ \\
DCM drive Power electronics & Thyristor \\
Snubber resistance\& capacitance $R_{s}, C_{s}$ & $3 \mathrm{~K} \Omega, 31.5 \mu \mathrm{F}$ \\
Forward voltage $V_{f} \& R_{\text {on }}$ & $1.3 \mathrm{~V}, 0.164 \Omega$ \\
Drive filtering inductance $L_{D}$ & $50 \mathrm{mH}$ \\
MV Cable Parameters & $\mathrm{XLPE}$ \\
resistance\& inductance, $R_{M V}, L_{\mathrm{MV}}$ & $3.15 \mathrm{~m} \Omega, 7.32 \mu \mathrm{H}$ \\
LV Cable Parameters & $\mathrm{XLPE}$ \\
resistance\& inductance, $R_{L V}, L_{\mathrm{LV}}$ & $0.476 \mathrm{~m} \Omega, 1.432 \mu \mathrm{H}$ \\
3 Phase step down Transformer & $\mathrm{DYn}, 6.3 \mathrm{KV} / 660 \mathrm{~V}$ \\
Nominal power \&frequency & $950 \mathrm{KVA}, 50 \mathrm{HZ}$ \\
MV winding resistance\& inductance & $1.037 \Omega, 23.46 \mathrm{mH}$ \\
LV winding resistance\& inductance & $3.792 \mathrm{~m} \Omega, 85.821 \mu \mathrm{H}$ \\
\hline
\end{tabular}

\section{APPENDIX II}

The Devices used in practical measurements in this study are:

1. HIOKI PW3198 Power quality analyzer with PQA-HiVIEW PRO software

2. CHAUVIN ARNOUX C.A 8335\&C.A 8334B energy analyzers with Quali-star software.

3. MCE-Gold 2.4 Motor parameters Analyzer.

\section{APPENDIX III}

APF and its control circuit parameters

\begin{tabular}{cc}
\hline Smoothing filter parameters & \\
Series Filter inductance\& resistance, $L_{f}, R_{f 1}$ & $1.25 \mathrm{mH}, 1 \mathrm{~m} \Omega$ \\
shunt Filter capacitance\& resistance, $C_{f}, R_{f 2}$ & $743.5 \mu \mathrm{F}, 1 \Omega$ \\
Filter DC capacitor, $C_{d c}$ & $4700 \mu \mathrm{F}$ \\
Power device (VSI) parameters & \\
IGBT internal resistance $R_{o n}$ & $10 \mathrm{~m} \Omega$ \\
Snubber resistance\& capacitance, $, R_{s}, C_{s}$ & $5 \mathrm{~K} \Omega, 0.05 \mu \mathrm{F}$ \\
PI Voltage regulator system parameters: & 0.06 \\
Proportional gain for voltage regulator & 0.0009 \\
integral gain for voltage regulator & $1500 \mathrm{~V}$ \\
DC reference voltage, $V_{d c}$ & \\
\hline
\end{tabular}

Journal of Engineering Sciences, Assiut University, Faculty of Engineering, Vol. 41, No. 6, November, 2013,E-mail address: jes@aun.edu.eg 
Gaber EL-Saady et al., Design and simulation of shunt active power filter for Assiut cement company DC motor drive, pp. 2244 - 2259

تصميم ومحاكاة مرشح قدرة فعال لمشغل محرك تيار ثابت بمصنع اسمنت أسيوط

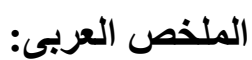

تُقدم هذه الورقة تصميم و محاكاة لمرشح القدرة الفعال القادر علي التاقلم تحت ظروف التشغيل المختلفة

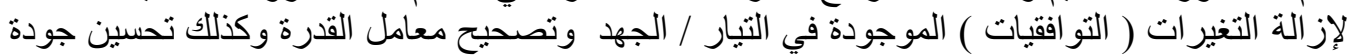

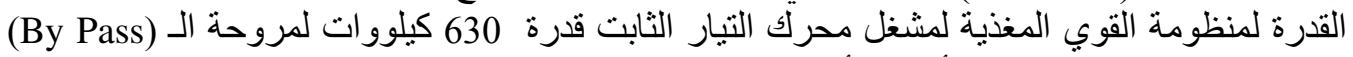
بخط الإنتاج رقم 2 في مصنع أسمنت أسيوط.

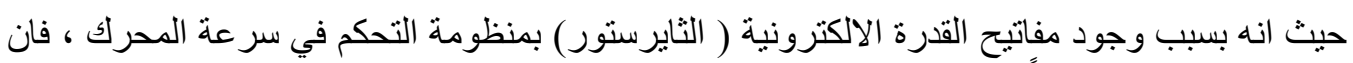

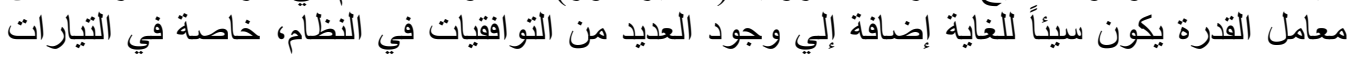

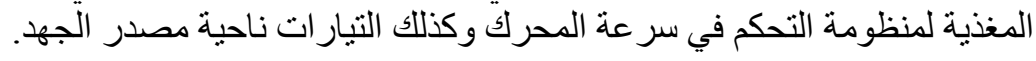

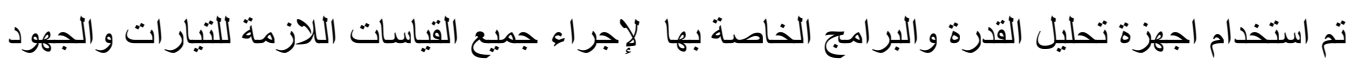

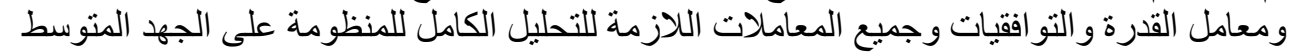

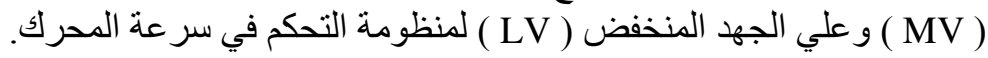

تم بناء نموذج باستخدام برنامج (MATLAB Simulink ) لتمثيل المنظومة ومحاكاة تشغيلها وكان

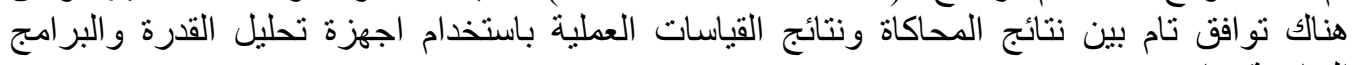

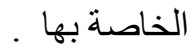

تم استخدم نظرية القوى اللحظية في تصميم مرشح القدرة الفعال التوازي باستخدام برنامج

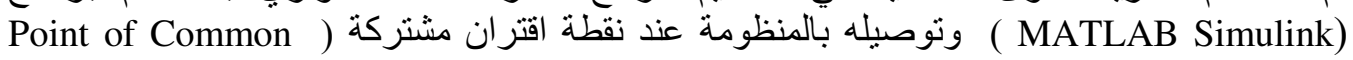

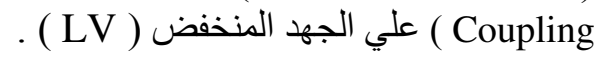

أظهرت نتائج المحاكاة للمنظومة كاملة باستخدام مرشح القدرة الفعال انخفاض التو افقيات الموجودة في

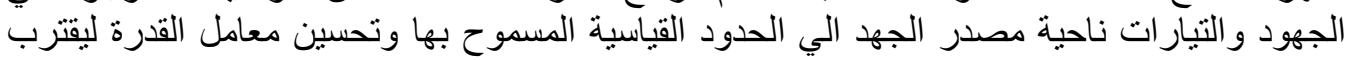
من الواحد الصحيح وكذلك تحسين جودة القدرة ومن ثم تقليل الفقد و التكاليف في منظومة القدرة الكهربية.

Journal of Engineering Sciences, Assiut University, Faculty of Engineering, Vol. 41, No. 6, November, 2013,E-mail address: jes@aun.edu.eg 